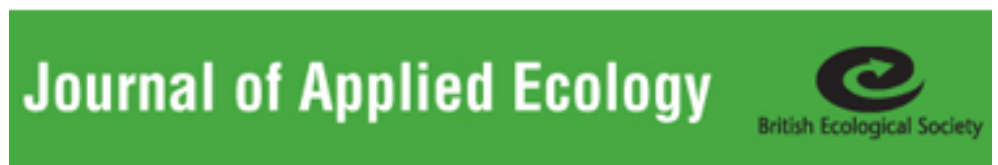

\title{
Methods of enhancing botanical diversity within field margins of intensively managed grassland: a seven year field experiment
}

\begin{tabular}{|c|c|}
\hline Journal: & Journal of Applied Ecology \\
\hline Manuscript ID: & JAPPL-2010-00689 \\
\hline Manuscript Type: & Standard Paper \\
\hline $\begin{array}{l}\text { Date Submitted by the } \\
\text { Author: }\end{array}$ & 13-Sep-2010 \\
\hline Complete List of Authors: & $\begin{array}{l}\text { Fritch, Rochelle; University College Dublin, School of Agriculture, } \\
\text { Food Science and Veterinary Medicine; Teagasc, Environmental } \\
\text { Research Centre } \\
\text { Sheridan, Helen; University College Dublin, School of Agriculture, } \\
\text { Food Science and Veterinary Medicine } \\
\text { Finn, John; Teagasc, Environmental Research Centre } \\
\text { Kirwan, Laura; Waterford Institute of Technology } \\
\text { Ó hUallacháin, Daire; Teagasc, Environmental Research Centre }\end{array}$ \\
\hline Key-words: & $\begin{array}{l}\text { wildflower seed mixture, plant diversity, margin width, grazing, hay } \\
\text { cutting, pasture, natural regeneration, field margin }\end{array}$ \\
\hline
\end{tabular}


1 Methods of enhancing botanical diversity within field margins of intensively managed 2 grassland: a seven year field experiment

3 Rochelle A. Fritch ${ }^{1,2}$, Helen Sheridan ${ }^{1}$, John A. Finn ${ }^{2}$, Laura Kirwan ${ }^{3}$, Daire Ó hUallacháin ${ }^{2}$

4 6

${ }^{1}$ School of Agriculture, Food Science and Veterinary Medicine, University College Dublin, Belfield, Dublin 4, Ireland.

${ }^{2}$ Teagasc, Environment Research Centre Johnstown Castle, Wexford, Ireland.

${ }^{3}$ Centre for Scientific Computing, Waterford Institute of Technology, Co. Waterford, Ireland.

\section{Corresponding author:}

Rochelle Fritch

Teagasc Environment Research Centre

Johnstown Castle

Wexford

Ireland

Phone: +353 539171264

Fax: +353539142273

Email: rochelle.fritch@gmail.com

Running title: Plant diversity in grassland field margins

Word count

Total: 6,958

Summary: 324

Main text: 3,803

Acknowledgements: 38

References: 1,442

Tables \& Figures: 1,351

No. of tables: 6

No of figures: 4

Number of references: 52 


\section{Summary}

1. Increased intensification has led to well-documented declines in the flora associated with agricultural grasslands. Manipulation of field margins for biodiversity enhancement in arable systems has been extensively investigated. However, there is a paucity of corresponding long-term research within intensively managed grasslands.

2. We investigated a combination of establishment and management methods to enhance botanical diversity of field margins in intensively managed grassland systems. The method of field margin establishment was investigated by fencing, natural regeneration by rotavation, or seeding with a wildflower mixture. Subsequent sward management by either grazing or mowing was tested at three margin widths. Success of establishment was addressed in terms of persistence of species richness, plant community composition and incidence of noxious weeds.

3. Seeding with a wildflower mixture was the most successful establishment treatment to enhance plant species richness and this effect persisted throughout the seven years of the experiment $\left(\bar{x}=16.08 \pm 0.50\right.$ s.e. plant species richness per $1 \times 3 \mathrm{~m}^{2}$ quadrat $)$. Fenced and rotavated treatments contained significantly fewer plant species per quadrat $(\bar{x}=8.01 \pm 0.36$ s.e., $\bar{x}=9.57 \pm 0.39$ s.e. respectively $)$.

4. Grazing led to a modest increase in species richness in fenced and rotavated plots compared to the mowing treatment, but had no effect in seeded plots. Grazing also led to an increased frequency and cover of competitive grasses in the seeded treatment.

5. While margin width was not found to significantly influence species richness, increased herb cover and reduced abundance of noxious weeds was recorded within the wider, seeded margins.

6. Synthesis and applications Choice of establishment method and subsequent management of grassland field margins significantly affected their conservation value. 
Botanical diversity of margins within intensively managed pasture can be enhanced by sowing wildflower seed mixtures. This diversity can be maintained over time through appropriate management. Minimal change management approaches currently adopted in many agri-environment schemes, such as cessation of nutrient inputs and/or fencing, did not produce field margin swards of conservation value.

Key words: wildflower seed mixture, plant diversity, margin width, grazing, hay cutting, pasture, natural regeneration

\section{Introduction}

Changes in grassland management, such as increased use of inorganic fertiliser, increased stocking rates, frequency of sward reseeding with species monocultures and a move from hay to silage production, have led to dramatic decreases in the biodiversity associated with agricultural grasslands (Frame 2000, Blackstock et al. 1999). These losses have affected all aspects of farmland biodiversity, including plants (Vickery et al. 2001, Stehlik et al. 2007), invertebrates (Benton et al. 2002; Fenner \& Palmer 1998), and birds (Donald et al. 2001 \& 2006).

Many floral and faunal species would have restricted ranges or be absent altogether from intensively farmed land were it not for field boundary and field margin habitats (Marshall \& Moonen 2002). Changes in field margin management, such as sowing wildflower mixtures or reducing of pesticide inputs, have been shown to increase farmland biodiversity within arable ecosystems (Asteraki et al. 2004; Critchley et al. 2006). However, corresponding methods of field margin enhancement within grassland systems largely remain unexplored (but see Haysom et al. 2004; Cole et al. 2007; Sheridan et al. 2008). We know of no studies that have specifically addressed the long-term development of botanically diverse grassland field margin swards. 
1 Grassland conservation research primarily focuses on reduction of management intensity over

2 entire fields or larger areas. While these aims are important, they do little to address the decline of diversity associated with improved grasslands. Furthermore, uptake of agrienvironmental measures in intensive areas has been low (Hynes et al. 2008). Intensive farms may be more likely to participate in conservation efforts if these are focused on contained, well defined areas, and therefore do not interfere with overall farm production levels.

The creation of new habitats within intensively managed agricultural land can promote beneficial organisms for biological control, foster ecological resilience by increasing local alpha diversity (Duelli \& Obrist 2003) and can act as 'island' refuges facilitating the movement of species between patches of semi-natural habitats (Albrecht 2010). Furthermore, field margin diversity may be particularly important for the maintenance of higher trophic level species, particularly farmland birds (Marshall \& Moonen 2002).

High soil nutrient levels are often associated with reduced botanical diversity and the dominance of a few, highly competitive species in grasslands (Kleijn et. al 2009). Decreasing soil fertility may lead to swards of conservation value, but results vary and largely depend on soil type and previous management (Smith et al. 2000; Warren, Christal \&Wilson 2002).

Natural regeneration is the only method of field margin establishment which preserves the local flora. If this method is employed then the potential diversity of the field margin is a function of the seeds coming from local sites or from the seed bank (Asteraki et al. 2004). Some studies suggest that natural regeneration of field margin vegetation promotes local invertebrate taxa equally as well as sown margins (Thomas \& Marshall 1999, Anderson \& Purvis 2008).

However, the success of grassland restoration is often seed-limited (Bakker \& Berendse 1999) as the lower botanical diversity associated with intensively managed grasslands generally results in a less diverse soil seed bank. Most 'desirable' grassland species have significantly 
1 shorter seed longevity than arable and ruderal species (Bossuyt \& Hermy 2003), with only a

2 few common species producing large, persistent seed banks (Bekker et al. 1997)

3 Reintroduction of botanical diversity, through the use of seed mixtures, has been successful in

4 the restoration of both arable (Martin \& Wilsey 2006) and intensively managed grasslands

5 (Jefferson 2005). However, this technique has not been applied to grassland field margins (but

6 see Hovd 2008).

7 Temporal persistence of floral diversity within sown arable field margins is a difficulty which has been attributed to lack of disturbance (Pywell et al. 2006). Within grassland systems, grazing herbivores can potentially increase levels of disturbance. However, success is largely dependent on intensity of grazing (Bullock et al. 1994), herbivore type (Vickery et al. 2001) and timing of grazing (Smith \& Rushton 1994).

This study investigated whether botanical diversity within field margins on intensively managed lowland grasslands can be enhanced by: (1) method of establishment, (2) modification of management, and (3) increased margin width. Success of these methods,

Site location \& description

The experiment was undertaken on a lowland dairy farm at the Teagasc Research Centre, 
1 hedgerows were removed in the 1970's and paddocks separated by electric wire. The area was

2 sown with a mid-season yielding variety of Lolium perenne approximately 4 years before the experiment commenced. Paddocks were grazed at a stocking rate of between 2.4-2.8 livestock units ha ${ }^{-1}$ by a Friesian dairy herd on a 21 day rotation and cut for silage in alternate years. Between 200-375 kg ha ${ }^{-1}$ nitrogen (N), 0-50 kg ha ${ }^{-1}$ phosphorous (P) and 0-75 $\mathrm{kg} \mathrm{ha}^{-1}$ potassium $(\mathrm{K})$ were applied annually to the swards adjacent to the experimental plots from 2002-2008.

\section{Experimental Design}

A stratified randomised factorial split-plot field margin experiment was established in spring 2002. Nine 90m long strips of grass sward were fenced off from the surrounding paddocks.

One of three field margin widths (1.5. 2.5, and 3.5m) was randomly assigned to each strip to provide three replicates of each width (see Fig. S1 in Supporting Information).

Three establishment treatments investigated were: (1) fenced off from the main part of the sward ('fenced'), (2) rotavated and allowed to regenerate naturally from the seed bank ('rotavated'), and (3) rotavated and seeded with a grass and wildflower mixture ('seeded'). Vegetation was removed prior to rotavation and reseeding, using a glyphosate herbicide at recommended application rates. The seed mixture contained 10 grass and 31 herb species (Table 1) and the mixture was sown at a rate of $2.5 \mathrm{~g} \mathrm{~m}^{-2}$. Control plots consisted of existing pasture vegetation which were grazed but had no subsequent application of nutrients or herbicide. Each 90m strip was divided into three sections and an establishment method was randomly allocated to each $30 \mathrm{~m}$ section. Fencing was used to exclude grazing from all treatment plots during the establishment period from February 2002 to June 2003.

All establishment treatment plots were mown and the clippings removed in September 2002. During June 2003, plots were split and half of each (randomly selected) grazed on a 21-day rotation basis in conjunction with the main sward ('grazed' treatment). The ungrazed portion 
1 of each plot was mown annually in September and all vegetation clippings removed ('mown'

2 treatment). Nutrient and pesticide inputs were excluded from all plots over the duration of the experiment, although grazed plots, including the controls, received dung and urine inputs from the cattle.

\section{Botanical Sampling}

Botanical data were collected using permanent, nested quadrats. Two, four and six 1 x 3m quadrats were taken from the 1.5, 2.5 and $3.5 \mathrm{~m}$ wide margins respectively (see Fig. S2). Presence/absence data were recorded for the entire $1 \times 3 \mathrm{~m}$ quadrat. Percentage cover of each species in the central $1 \mathrm{~m}^{2}$ was visually estimated according to the Braun-Blanquet scale (Braun-Blanquet, Fuller \& Conrad 1932). To avoid edge effects, a 9m long strip between treatments was not sampled. Plots were sampled in July of 2002, 2003, 2007, and 2008. Here, data from 2003, 2007 and 2008 were analysed while 2002 was treated as an establishment period (see Sheridan et al. 2008). Species were identified according to Stace (1997).

\section{Soil sampling}

Soil samples, consisting of twenty pooled $10 \mathrm{~cm}$ depth cores, were taken from each plot in February 2003 and 2008. Samples were analysed to investigate levels of Morgan's available P, K, and Mg (Jackson 1958, Murphy \& Reilly 1962).

Data analyses

A repeated measures analysis of total species richness per 1 x $3 \mathrm{~m}$ quadrat was undertaken, using GLIMMIX (SAS 9.1.3) and a spatial covariance matrix, to account for permanency of quadrat location. Effects of establishment treatment, grazing, width, and time on species richness were investigated with all interactions between factors included in the full model. Initial maximal models were refined by the sequential removal of all non-significant terms. Minimal adequate models were identified by a process of assessment before and after the 
1 removal of terms using Akaike's Information Criterion (AIC) (Akaike 1974). All tests of

2 significance were at the $\mathrm{p}<0.05$ level.

3 For each plot species turnover (which is equivalent to 1 - Sørensen's similarity index) between two years was calculated as:

$5 \quad t=\frac{b_{i}+c_{j}}{S_{i}+S_{j}}$

where $\mathrm{b}_{i}=$ the number of species present in a plot that are unique to year $i$; $\mathrm{c}_{\mathrm{j}}=$ the number of species present in a plot that are unique to year $\mathrm{j} ; \mathrm{S}_{i}=$ the total number of species present in a plot in year $i$; and $\mathrm{S}_{j}=$ the total number of species present in a plot in year $j$ (Magurran 2004).

Plant community dynamics were investigated further by dividing species into three groups: 1) weed species (species listed on the Irish Noxious Species Act 1936 and including Senecio jacobaea, Rumex obtusifolius, $R$. crispus, Cirsium arvense and C. vulgare); 2) herbaceous species (excluding weeds) and 3) grass species (monocotyledonous species). Species richness and changes in abundance were analysed for each of these groups using a nonparametric factorial analysis as in Brunner \& Puri (2001) using Proc Mixed (SAS 9.1.1) with repeated measures and a spatial covariance matrix. This method was used as the data were zero inflated and could not be analysed using parametric methods.

Multivariate analysis using CANOCO 4.5 was used to investigate the main effects of establishment treatment, grazing, width and their interactions, on the plant community composition. A partial Redundancy Analysis (RDA) was performed using species percentage cover data that were averaged across quadrat sub-samples within each replicate plot and centred by species, with the Monte Carlo permutation test (reduced model, 9999 permutations restricted to six split-plots, freely exchangeable whole-plots, no permutation at the split plot level). Partial RDA was used as plots had a homogeneous composition and showed linear species responses (Leps \& Smilauer 2003). 
1 In addition, differences in end-point vegetation composition for each establishment treatment

2 x grazing management were tested in six separate RDA analyses of the null hypothesis that treatment $X$ differed from treatment $Y$. Significance tests were performed by Monte Carlo permutation tests after 9999 unrestricted permutations, as only one environmental variable (treatment) was considered.

A Principal Response Curve (PRC) graphically demonstrated the change in plant species composition for each establishment treatment $\mathrm{x}$ grazing management interaction, over time, with the grazed control as the reference zero line. PRCs were based on partial RDA with time as a co-variable and treatment $\mathrm{x}$ time interactions set as environmental variables. Within these analyses, the average temporal trend was removed by treating it as a continuous covariate.

The PRC diagrams correspond to the first and second RDA axes with species highly correlated to each axis displayed to the right of the diagram.

\section{Results}

A total of 76 higher plant species were recorded during the experiment. This included 50 herb, 17 grass, five woody, three rush, and one sedge species. A summary of species recorded with $>5 \%$ frequency can be seen in Table 1. For simplicity, only data from 2003 and 2008 are presented. In 2003, 16 of the 31 herb species and all of the 10 grass species included in the seed mixture were recorded. In 2008 the number of seeded herbs had reduced to 11 while all 10 grass species persisted (Table 1). A full list of species recorded within each treatment can be seen in the supporting information (Table S1).

\section{Effect of establishment method}

Method of field margin establishment had the greatest influence on botanical species richness $(\mathrm{p}<0.0001$, Table 2, Table 3 Fig. 1a), with an increase from 4.5 species per quadrat in control plots to 15.3 species per quadrat in the seeded plots in 2003. This increased species richness 
1 within seeded plots was maintained over the full experimental period with seeded plots

2 having the greatest species richness, followed by rotavated plots, and then fenced plots ( $\mathrm{p}<$ 0.0001). Species richness of herbs showed a similar trend $(\mathrm{p}<0.0001$, Fig $1 \mathrm{~b})$. Total species richness also increased within the rotavated and fenced treatments; however, species richness was always significantly higher in rotavated plots than in fenced ones. This increase in species richness may be partially attributed to the movement of species from the seeded plots. For example, Cynosurus cristatus and Alopecurus pratensis were not present in the fenced and rotavated treatments during 2003, but were recorded there in 2008 (Table 1).

Herb cover was also greatest in seeded plots during all sampling years $(\mathrm{p}<0.0001$, Fig. $1 \mathrm{c})$. There was a significant establishment treatment $\mathrm{x}$ time interaction $(\mathrm{p}<0.0001$, Table 3$)$. The fenced and rotavated plots showed significant increases in herb cover from 2003 to 2008 ( $\mathrm{p}<$ 0.0001 and $\mathrm{p}=0.0003$ respectively), while seeded plots did not.

\section{Effect of grazing}

The interaction between grazing and establishment treatment was significant for total species richness ( $p=0.0017$, Fig. 1a, Table 2). In seeded plots, grazing had no significant impact on species richness, while in fenced and rotavated plots grazing significantly increased species richness. Grazing increased the frequency of competitive grass species (Lolium perenne and Poa trivialis) in rotavated and seeded plots (Table 1).

\section{Effect of field margin width}

There was a significant interaction between width and establishment treatment (Table 2, Fig.2a), with $2.5 \mathrm{~m}$ rotavated plots having higher species richness than $1.5 \mathrm{~m}$ and $3.5 \mathrm{~m}$ rotavated plots ( $\mathrm{p}=0.013$ and $\mathrm{p}=0.044$ respectively). Seeded plots showed a trend of increasing species richness with width, although this was not significant. Fenced plots showed an opposite trend, with species richness decreasing over increasing margin widths, i.e. species richness was significantly greater in the $1.5 \mathrm{~m}$ than in the $3.5 \mathrm{~m}$ plots $(\mathrm{p}=0.046)$. A significant 
1 interaction was found between herb cover and plot width, ( $p=0.04$, Fig. 2b, Table 3), with

$23.5 \mathrm{~m}$ seeded margins containing a higher herb cover than $1.5 \mathrm{~m}$ margins $(\mathrm{p}=0.031)$.

\section{Noxious weeds}

Cover of noxious weed was significantly greater in rotavated plots compared to seeded $(\mathrm{p}=$ $<0.0001$ ) or fenced plots ( $<<0.0001$; Fig 1d, Table 3 ) and generally decreased over time (Fig. 1d). This can largely be attributed to reductions in cover of Rumex species and $C$. vulgare over time (Table 1). Grazing did not significantly influence weed cover, however, the interaction between margin width and establishment treatment was significant $(p=0.002$, Table 2). In seeded plots, weed cover decreased as width increased ( $p<0.05$; Fig. $2 c)$.

\section{Species turnover}

There was a significant interaction between establishment treatment and turnover period (Table 4, $\mathrm{p}<0.0001$ ). Relative species turnover was significantly higher in the seeded and rotavated plots during the initial period compared with fenced plots (Fig. 3). This was primarily due to the loss of ruderal species in these plots following the establishment period. There was also a significant interaction between grazing and turnover period $(\mathrm{p}=0.012$, Table 4). Grazing did not affect turnover in the establishment period from 2002 to 2003 (Table 4). However grazing caused a significantly increased species turnover in the short term from 2007 to 2008 and in long-term from 2003 to 2008. Turnover from 2007 to 2008 was similar in all plots (c. $20 \%$ per year) with the exception of those which were seeded and mown, where it was significantly lower, c. $12 \%$ per year and this indicated the most stable plant community (Table 4).

\section{Plant community composition}

The Monte Carlo test showed a significant effect of establishment treatment, width, and grazing, as well as an interaction between these factors on the plant species composition (Table 6). By 2008 most plant communities were significantly different from each other, with 
1 the exception of those in the 'rotavated \& mown' treatment and the 'mown' treatment, which

2 had converged over time (Table 5).

The principal response curve for the first RDA axis showed a clear distinction in plant community structure between the seeded \& mown treatments compared with all others (Fig.

4a). These plots also displayed stability in community composition over time (as also indicated by turnover), while the composition of all other treatment plots moved towards the grazed control situation (zero line). The principal response curve for the second RDA axis (Fig. 4b) primarily showed the effect of grazing, with community composition of the grazed plots clustering near the control (zero line), while the mown plots clustered together.

Soil

Grazing led to an increase in available soil magnesium and potassium compared to the mown plots, but had no effect on soil phosphate levels in 2008(see Table S2 \& Table S3).

\section{Discussion}

\section{Establishment method}

This study demonstrated that use of seed mixtures produced the highest species richness and herbaceous cover in experimental field margins over the seven year experiment. Within this intensively managed grassland system the seed bank and rain were not sufficient to improve species richness over the duration of the experiment. These findings concur with many studies on grassland restoration which have found that restoration tends to be propagule-limited (Bakker \& Berendse 1999, Pywell et al. 2002, Martin \& Wilsey 2006) and therefore requires the addition of seed to increase species richness. Although species richness increased within rotavated and fenced plots over time, this may have been due to the migration of seeded species into adjacent plots through wind dispersal or while plots were being cut (through the movement of clippings). 
1 The use of a seed mixture was also found to increase herbaceous cover and decrease noxious

2 weed cover. Rotavation gave rise to problems with noxious weeds and there was little successful herb establishment from the seed bank. These results support our assertion that use of a seed mixture is appropriate when margins have been degraded by intensification and there are limited seed resources locally. However, introduction of seed mixtures may not be appropriate in extensively managed grasslands or where appropriate species are found locally in the landscape. Under such conditions seed rain may be sufficient to enhance margin diversity when coupled with appropriate management, such as reduced nutrient inputs and moderate grazing and/or mowing. These methods have been used successfully in some grassland restoration projects where the management history was less intensive (Walker et al. 2004).

\section{Field margin management}

Plant community composition was significantly affected by subsequent management of the field margin. Paddock grazing practiced at this site, and which is the norm within intensively managed pastoral systems in general, results in low and uniform sward height with few species capable of setting seed (Vickery et al. 2001). Over the experimental period, the plant community composition of all the grazed plots became more similar to the control plots, with increased frequency of competitive grass species. On the other hand, plots which were mown once annually were subject to lower levels of disturbance. Where soil nutrient status is high, this lack of disturbance can lead to low levels of seedling recruitment, as established vegetation can quickly out-compete seedlings for light (Hautier, Niklaus \& Hector 2009).

Under these experimental conditions mowing led to a more stable sward community composition, with lower species turnover rates than were recorded in grazed plots. It is likely that a disturbance level between these extremes may have promoted enhanced seedling recruitment and sward stability. Hay meadows usually have both mowing and grazing management. Seedling emergence is enhanced by manual soil disturbance (to simulate 
1 aftermath grazing) after mowing (Hellström et al. 2009). The implications for plant

2 biodiversity rest in the minor alterations in management, such as the timing and frequency of both mowing and grazing (Coulson et al. 2001). There is a lack of data comparing the effectiveness of mowing versus grazing in the restoration of biodiversity in grasslands (Pykala 2000). Increases in biodiversity may be achieved through the manipulation of disturbance through the timing, intensity and frequency of grazing, to produce more micro-sites for seedling germination (Bullock 1994). The use of grazing to manipulate disturbance rates may be more appropriate than mowing in pasture field margins, as herbivores are readily available and it simplifies management for farmers. Making management options more practical attracts farmers to AES and may lead to wider participation (Morris, Mills, \& Crawford 2000).

\section{Margin width}

Wider margins, with their increased area, should theoretically lead to decreased extinction risk and thus higher species richness (MacArther \& Wilson 1967). While width seemed less important than seeding and sward management in determining species richness of plots it appeared to be an essential factor in the successful establishment of sown plant communities. Wider margins facilitated increased cover of herb species within sown margins, while reducing the dominance of noxious perennial weeds. According to Joshi (2006), specialist species tend to be lost when grassland patch size is small whereas generalist plant species remain constant. The retention of less competitive perennial herb species, and thus the conservation quality of seeded grassland field margins, may be determined by margin width.

Within the Irish context, field sizes are relatively small ( $\bar{x}=3.93$ ha.) and over $70 \%$ of the fields are smaller than 4 ha. (Deverell, McDonnell \& Devlin 2009). Therefore, the establishment of a $6 \mathrm{~m}$ margin, a width that is generally recommended in many agrienvironment schemes, along all field edges would be inappropriate as it could constitute $12 \%$ 
1 of the average field area. A more rational approach would be to dedicate a percentage of the

2 productive area (for example 1-4\%) of the farm to seeded and expanded margins.

\section{Implications for enhancing field margins within intensive grasslands}

With investment in agri-environment schemes costing €3.7 billion annually in the EU (OECD 2004), new policy measures must show clearly identifiable and measurable biodiversity benefits. This research shows that there are more efficient measures for the enhancement of plant diversity within grassland systems than current policy reflects.

Cessation of nutrient inputs alone was not sufficient to restore plant diversity. While this is essential to ensure further diversity is not lost, it is of potentially limited value in terms of enhancing botanical diversity over an agri-environment contact period (see Sheridan, Finn \& O'Donovan 2009).

Our results imply that under intensive grazing systems, plant diversity can be enhanced through the introduction of seed mixtures and this diversity can be maintained over time.

\section{Acknowledgments}

Special thanks to Donncha Madden, Mairead Shore, Anna Bunyan, Oisin Murphy, Michelle

Moran and Giles King-Salter. This project was funded by the Department of Agriculture, 
1

\section{References}

Akaike, H. (1974) New look at statistical-model identification. IEEE Transactions on Automatic Control, AC19, 716-723.

Albrecht, M., Schmid, B., Obrist, M. K., Schüpbach, B., Kleijn, D. \& Duelli, P. (2010) Effects of ecological compensation meadows on arthropod diversity in adjacent intensively managed grassland. Biological Conservation, 143, 642-649.

Anderson, A. \& Purvis, G. (2008) The value of parasitic hymenoptera as indicators of biological diversity. Final report for Project 2003-FS-CD-LS-14-M1 Environmental RTDI Programme 2000-2006. Environmental Protection Agency, Johnstown Castle, Wexford.

Asteraki, E. J., Hart, B. J., Ings, T. C. \& Manley, W. J. (2004) Factors influencing the plant and invertebrate diversity of arable field margins. Agriculture, Ecosystems \& Environment, 102, 219-231.

Bakker, J. P. \& Berendse, F. (1999) Constraints in the restoration of ecological diversity in grassland and heathland communities. Trends in Ecology \& Evolution, 14, 63-68.

Bekker, R. M., Verweij, G. L., Smith, R. E. N., Reine, R., Bakker, J. P. \& Schneider, S. (1997) Soil seed banks in European grasslands: Does land use affect regeneration perspectives? Journal of Applied Ecology, 34, 1293-1310.

Benton, T. G., Bryant, D. M., Cole, L. \& Crick, H. Q. P. (2002) Linking agricultural practice to insect and bird populations: a historical study over three decades. Journal of Applied Ecology, 39, 673-687.

Blackstock, Rimes, Stevens, Jefferson, Robertson, Mackintosh \& Hopkins (1999) The extent of semi-natural grassland communities in lowland England and Wales: a review of conservation surveys 1978-96. Grass and Forage Science, 54, 1-18.

Bossuyt, B. \& Hermy, M. (2003) The potential of soil seedbanks in the ecological restoration of grassland and heathland communities. Belgian Journal of Botany, 136, 23-34. 
1 Braun-Blanquet, J., Fuller, G. D. \& Conrad, H. S. (1932) Plant sociology : the study of plant communities. McGraw-Hill Inc., New York, U.S.A.

Brunner, E. \& Puri, M. L. (2001) Nonparametric methods in factorial designs. Statistical Papers, 42, 1-52.

Bullock, J. M., Hill, B. C., Dale, M. P. \& Silvertown, J. (1994) An experimental study of the effects of sheep grazing on vegetation change in a species-poor grassland and the role of seedling recruitment into gaps. Journal of Applied Ecology, 31, 493-507.

Cole, L. J., McCracken, D. I., Baker, L. \& Parish, D. (2007) Grassland conservation headlands: Their impact on invertebrate assemblages in intensively managed grassland. Agriculture, Ecosystems \& Environment, 122, 252-258.

Coulson, S. J., Bullock, J. M., Stevenson, M. J. \& Pywell, R. F. (2001) Colonization of grassland by sown species: dispersal versus microsite limitation in responses to management. Journal of Applied Ecology, 38, 204-216.

Critchley, C. N. R., Fowbert, J. A., Sherwood, A. J. \& Pywell, R. F. (2006) Vegetation development of sown grass margins in arable fields under a countrywide agrienvironment scheme. Biological Conservation, 132, 1-11.

Deverell, R., McDonnell, K. \& Devlin, G. (2009) The impact of field size on the environment and energy crop production efficiency for a sustainable indigenous bioenergy supply chain in the Republic of Ireland. Sustainability, 1, 994-1011.

Donald, P. F., Green, R. E. \& Heath, M. F. (2001) Agricultural intensification and the collapse of Europe's farmland bird populations. Proceedings of the Royal Society of London Series B-Biological Sciences, 268, 25-29.

Donald, P. F., Sanderson, F. J., Burfield, I. J. \& van Bommel, F. P. J. (2006) Further evidence of continent-wide impacts of agricultural intensification on European farmland birds, 1990-2000. Agriculture Ecosystems \& Environment, 116, 189-196. 
1

Duelli, P. \& Obrist, M. K. (2003) Regional biodiversity in an agricultural landscape: the contribution of seminatural habitat islands. Basic and Applied Ecology, 4, 129-138.

Fenner, M. \& Palmer, L. (1998) Grassland management to promote diversity: creation of a patchy sward by mowing and fertilizer regimes. Field Studies, 9, 313-324.

Frame, J. (2000) Improved Grassland Management. Farming Press.

Hautier, Y., Niklaus, P. A. \& Hector, A. (2009) Competition for light causes plant biodiversity loss after eutrophication. Science, 324, 636-638.

Haysom, K. A., McCracken, D. I., Foster, G. N. \& Sotherton, N. W. (2004) Developing grassland conservation headlands: response of carabid assemblage to different cutting regimes in a silage field edge. Agriculture, Ecosystems \& Environment, 102, 263-277.

Hellström, K., Huhta, A.-P., Rautio, P. \& Tuomi, J. (2009) Seed introduction and gap creation facilitate restoration of meadow species richness. Journal for Nature Conservation, 17, 236-244.

Hovd, H. (2008) Occurrence of meadow herbs in sown and unsown ploughed strips in cultivated grassland. Acta Agriculturae Scandinavica Section B-Soil and Plant Science, 58, 208-215.

Hynes, S., Farrelly, N., Murphy, E. \& O'Donoghue, C. (2008) Modelling habitat conservation and participation in agri-environmental schemes: A spatial microsimulation approach. Ecological Economics, 66, 258-269.

Jackson, M. L. (1958) Soil Chemical Analysis. Prentice-Hall Inc., Englewood Cliffs, New Jersey.

Jefferson, R. G. (2005) The conservation management of upland hay meadows in Britain: a review. Grass and Forage Science, 60, 322-331. 
1 Joshi, J., Stoll, P., Rusterholz, H. P., Schmid, B., Dolt, C. \& Baur, B. (2006) Small-scale experimental habitat fragmentation reduces colonization rates in species-rich grasslands. Oecologia, 148, 144-152.

Kleijn, D., Kohler, F., Baldi, A., Batary, P., Concepcion, E. D., Clough, Y., Diaz, M., Gabriel, D., Holzschuh, A., Knop, E., Kovacs, A., Marshall, E. J. P., Tscharntke, T. \& Verhulst, J. (2009) On the relationship between farmland biodiversity and land-use intensity in Europe. Proceedings of the Royal Society B-Biological Sciences, 276, 903-909.

Leps, J. \& Smilauer, P. (2003) Multivariate analysis of ecological data using CANOCO. Cambridge University Press, Cambridge.

MacArthur, R. H. \& Wilson, E. O. (1967) The theory of island biogeography. Princeton University Press, Princeton.

Magurran, A. E. (2004) Measuring biological diversity. Blackwell, Oxford.

Marshall, E. J. P. \& Moonen, A. C. (2002) Field margins in northern Europe: their functions and interactions with agriculture. Agriculture, Ecosystems \& Environment, 89, 5-21.

Martin, L. M. \& Wilsey, B. J. (2006) Assessing grassland restoration success: relative roles of seed additions and native ungulate activities. Journal of Applied Ecology, 43, 10981109.

Morris, J., Mills, J. \& Crawford, I. M. (2000) Promoting farmer uptake of agri-environment schemes: the Countryside Stewardship Arable Options Scheme. Land Use Policy, 17, 241-254.

Murphy, J. J. \& Reily, J. P. (1962) A modified single solution method for the determination of phosphate in natural waters. Analytica Chimica Acta, 27, 31-36.

OECD (2004) Agriculture and the Environment: Lessons Learned from a Decade of OECD Work. Paris 
Pykala, J. (2000) Mitigating human effects on European biodiversity through traditional animal husbandry. Conservation Biology, 14, 705-712.

Pywell, R. F., Bullock, J. M., Hopkins, A., Walker, K. J., Sparks, T. H., Burke, M. J. W. \& Peel, S. (2002) Restoration of species-rich grassland on arable land: assessing the limiting processes using a multi-site experiment. Journal of Applied Ecology, 39, 294309.

Pywell, R. F., Warman, E. A., Hulmes, L., Hulmes, S., Nuttall, P., Sparks, T. H., Critchley, C. N. R. \& Sherwood, A. (2006) Effectiveness of new agri-environment schemes in providing foraging resources for bumblebees in intensively farmed landscapes. Biological Conservation, 129, 192-206.

Sheridan, H., Finn, J. A., Culleton, N. \& O'Donovan, G. (2008) Plant and invertebrate diversity in grassland field margins. Agriculture Ecosystems \& Environment, 123, 225-232.

Sheridan, H., Finn, J. A. \& O'Donovan, G. (2009) Botanical rejuvenation of field margins and benifits for invertebrate fauna on a drystock farm in Co. Longford. Biology and Environment-Proceedings of the Royal Irish Academy, 109B, 95-106.

Smith, R. S. \& Rushton, S. P. (1994) The effects of grazing management on the vegetation of mesotrophic (meadow) grassland in northern England. Journal of Applied Ecology, 31, 13-24.

Smith, R. S., Shiel, R. S., Millward, D. \& Corkhill, P. (2000) The interactive effects of management on the productivity and plant community structure of an upland meadow: An 8-year field trial. Journal of Applied Ecology, 37, 1029-1043.

Stace, C. A. (1997) New flora of the British Isles, 2nd ed. Cambridge University Press, Cambridge. 
1 Stehlik, I., Caspersen, J. P., Wirth, L. \& Holderegger, R. (2007) Floral free fall in the Swiss lowlands: environmental determinants of local plant extinction in a peri-urban landscape. Journal of Ecology, 95, 734-744.

Thomas, C. F. G. \& Marshall, E. J. P. (1999) Arthropod abundance and diversity in differently vegetated margins of arable fields. Agriculture Ecosystems \& Environment, 72, 131-144.

Vickery, J. A., Tallowin, J. R., Feber, R. E., Asteraki, E. J., Atkinson, P. W., Fuller, R. J. \& Brown, V. K. (2001) The management of lowland neutral grasslands in Britain: effects of agricultural practices on birds and their food resources. Journal of Applied Ecology, 38, 647-664.

Walker, K. J., Stevens, P. A., Stevens, D. P., Mountford, J. O., Manchester, S. J. \& Pywell, R. F. (2004) The restoration and re-creation of species-rich lowland grassland on land formerly managed for intensive agriculture in the UK. Biological Conservation, 119, $1-18$.

Warren, J., Christal, A. \& Wilson, F. (2002) Effects of sowing and management on vegetation succession during grassland habitat restoration. Agriculture Ecosystems \& Environment, 93, 393-402.

\section{Supporting Information}

Fig. S1. Diagram of experimental design.

Fig. S2. Diagram of botanical sampling.

Table S1. Presence/absence of species recorded in all years.

Table S2. Mean soil nutrient levels.

Table S3. Effects of establishment treatment, grazing and width on soil nutrient levels. 
Table 1. Summary of (a) changes in the frequency of plant species (with frequencies $>5 \%$ ) in permanent field margin quadrats between 2003 and 2008, ranked by most abundant species and (b) mean percentage cover of the ten most frequent species in 2008. $\mathrm{M}=$ Mown, $\mathrm{C}=$ grazed control, $\mathrm{R}+\mathrm{M}=$ rotavated $\&$ mown, $\mathrm{R}+\mathrm{G}=$ rotavated $\&$ grazed, $\mathrm{S}+\mathrm{M}=$ seeded $\&$ mown, $\mathrm{S}+\mathrm{G}=$ seeded $\&$ grazed. Categories: '--' is $<-50 \%$, '-' is $-50 \%$ to $-11 \%$, ' 0 ' is $-10 \%$ to $+10 \%$, ' + ' is $+11 \%$ to $50 \%$, ' ++ ' is $>50 \%$, blank spaces are absent from both years, * denotes species with cover $<1 \%$.

(a) \% frequency change 2003 to 2008

(b) Mean \% cover in 2008

\begin{tabular}{|c|c|c|c|c|c|c|c|c|c|c|c|c|}
\hline & M & $\mathrm{C}$ & $\mathrm{R}+\mathrm{M}$ & $\mathrm{R}+\mathrm{G}$ & $\mathrm{S}+\mathrm{M}$ & $\mathrm{S}+\mathrm{G}$ & M & $\mathrm{C}$ & $\mathrm{R}+\mathrm{M}$ & $\mathrm{R}+\mathrm{G}$ & $\mathrm{S}+\mathrm{M}$ & $\mathrm{S}+\mathrm{G}$ \\
\hline Agrostis spp $p^{\dagger}$ & 0 & 0 & 0 & 0 & 0 & 0 & 29 & 21 & 16 & 21 & 16 & 20 \\
\hline Holcus lanatus ${ }^{\dagger}$ & + & + & + & - & 0 & 0 & 32 & 26 & 27 & 24 & 12 & 18 \\
\hline Lolium perenne & - & 0 & 0 & 0 & - & ++ & 1 & 33 & & 15 & & 14 \\
\hline Rumex spp. & 0 & 0 & + & + & - & - & & & 4 & 3 & & \\
\hline Ranunculus repens & + & + & + & 0 & + & + & 5 & 2 & 11 & 8 & 6 & \\
\hline Rumex acetosa ${ }^{\dagger}$ & & + & - & & + & - & & & 1 & & 4 & 2 \\
\hline Cynosurus cristatus $^{\dagger}$ & 0 & + & & 0 & - & 0 & & & & & 2 & 4 \\
\hline Holcus mollis & + & 0 & 0 & + & + & 0 & 21 & 1 & 17 & & & \\
\hline Poa trivialis & 0 & ++ & 0 & 0 & + & ++ & & 5 & & 7 & & 2 \\
\hline Cirsium arvense & + & + & - & - & + & + & 4 & 1 & 8 & 4 & & \\
\hline Dactylis glomerata ${ }^{\dagger}$ & + & 0 & 0 & 0 & + & + & 4 & 2 & & & & \\
\hline Anthoxanthum odoratum ${ }^{\dagger}$ & & & + & & 0 & - & & & & & 3 & \\
\hline Arrhenatherum elatius ${ }^{\dagger}$ & + & & 0 & & + & - & 4 & & 11 & & 23 & \\
\hline Plantago lanceolata ${ }^{\dagger}$ & & 0 & & + & 0 & + & & & & & 7 & 14 \\
\hline Phleum pratense $e^{\dagger}$ & & & 0 & & -- & - & & & & & & \\
\hline Daucus carota ${ }^{\dagger}$ & & 0 & 0 & 0 & -- & - & & & & & & \\
\hline Cerastium fontanum & 0 & ++ & + & + & 0 & ++ & & 1 & & 1 & & 1 \\
\hline Alopecurus pratensis ${ }^{\dagger}$ & & 0 & 0 & 0 & + & 0 & & & & & 6 & \\
\hline Leucanthemum vulgare ${ }^{\dagger}$ & & & & & - & 0 & & & & & & 1 \\
\hline Epilobium spp & & + & 0 & 0 & - & - & & & & & & \\
\hline Senecio jacobaea & & - & 0 & + & + & + & & & 2 & 1 & & \\
\hline Trifolium repens & & + & + & 0 & 0 & + & & 2 & & 9 & & 9 \\
\hline Festuca rubra ${ }^{\dagger}$ & & & & & + & + & & & & & 4 & \\
\hline Juncus spp. & & & 0 & 0 & + & + & & & $*$ & & & \\
\hline Taraxacum agg. ${ }^{\dagger}$ & & - & & 0 & 0 & 0 & & & & & & \\
\hline Filipendula ulmaria $^{\dagger}$ & & & & & + & + & & & & & & \\
\hline Роа аппиа & & + & & ++ & & + & & & & & & \\
\hline Urtica dioica & & & 0 & + & 0 & & & & & & & \\
\hline Prunella vulgaris ${ }^{\dagger}$ & & & & & 0 & + & & & & & & \\
\hline Veronica serpyllifolia & & + & & 0 & & + & & & & & & \\
\hline Juncus bufonius & + & & & 0 & & + & $*$ & & & & & \\
\hline Cirsium vulgare & & & 0 & + & 0 & 0 & & & & & & \\
\hline Ranunculus acris ${ }^{\dagger}$ & & & & & + & 0 & & & & & & \\
\hline Lychnis flos-cuculi ${ }^{\dagger}$ & & & & & 0 & + & & & & & & \\
\hline Digitalis purpurea $^{\dagger}$ & & & & & - & - & & & & & & \\
\hline Elytrigia repens & + & & - & & + & & $*$ & & & & & \\
\hline Alopecurus geniculatus & & + & & & & + & & & & & & \\
\hline Achillea millefolium ${ }^{\dagger}$ & & & & & & 0 & & & & & & \\
\hline Centaurea nigra $^{\dagger}$ & & & & & + & & & & & & & \\
\hline Lotus corniculatus & & & 0 & & & 0 & & & & & & \\
\hline Quercus spp. & 0 & & & & 0 & & & & & & & \\
\hline Trifolium pratense & & & & & & - & & & & & & \\
\hline
\end{tabular}

Species included in the seed mixture are denoted by $\dagger$. Other species included within the seed mixture are: Alliaria petiolata, Angelica sylvestris, Anthyllis vulneraria, Arctium minus, Capsella bursa-pastoris, Dipsacus fullonum, Eupatorium cannabinum, Galium verum, Leontodon hispidus, Lythrum salicaria, Medicago lupulina, Origanum vulgare, Pedicularis palustris, Primula veris, Pulicaria dysenterica, Rhinanthus minor, Silene vulgaris, Succisa pratensis, and Vicia cracca. 
1 Table 2. Effects of treatment, year, grazing and width and the interactions of these factors, on total species 2 richness of the experimental plots over three sampling periods (2003, 2007 and 2008) calculated using 3 GLIMMIX.

\begin{tabular}{lcrr}
\hline & \multicolumn{3}{c}{ Total species } \\
& richness \\
& DF & \multicolumn{1}{c}{$\boldsymbol{F}$} & \multicolumn{1}{c}{$\boldsymbol{P}$} \\
\hline Establishment treatment & $(2,68)$ & 366.89 & $* * *$ \\
Grazing & $(1,76)$ & 68.15 & $* * *$ \\
Grazing x est. treatment & $(2,76)$ & 6.93 & $* *$ \\
Width & $(2,68)$ & 1.23 & n.s. \\
Width x est. treatment & $(4,68)$ & 2.83 & $*$ \\
Year x est. treatment & $(4,68)$ & 9.18 & $* * *$ \\
Year x grazing & $(2,76)$ & 9.24 & $* * *$ \\
\hline$* P<0.05 . * * P<0.01 . * * P<0.001$, & &
\end{tabular}

Table 3. Effects of treatment, year, grazing and width and the interactions of these factors, on the herb species richness, herb percentage cover, and weed percentage cover of the experimental plots over three sampling periods (2003, 2007 and 2008) calculated using nonparametric methods.

\begin{tabular}{|c|c|c|c|c|c|c|c|}
\hline & \multicolumn{3}{|c|}{$\begin{array}{l}\text { Herb species } \\
\text { richness }\end{array}$} & \multicolumn{2}{|c|}{$\begin{array}{l}\text { Herb percentage } \\
\text { cover }\end{array}$} & \multicolumn{2}{|c|}{$\begin{array}{l}\text { Weed percentage } \\
\text { cover }\end{array}$} \\
\hline & $\boldsymbol{F}$ & $\boldsymbol{P}$ & & $\boldsymbol{F}$ & $\boldsymbol{P}$ & $\boldsymbol{F}$ & $\boldsymbol{P}$ \\
\hline Year & 21.80 & & $* * *$ & 19.19 & $* * *$ & 14.56 & $* * *$ \\
\hline Establishment treatment & 217.36 & & $* * *$ & 126.32 & $* * *$ & 19.76 & $* * *$ \\
\hline Grazing & 41.28 & & $* * *$ & 4.79 & * & 1.93 & n.s. \\
\hline Grazing $\mathrm{x}$ est. treatment & 2.41 & & n.s. & 0.42 & n.s. & 0.01 & n.s. \\
\hline Width & 0.33 & & n.s. & 1.53 & n.s. & 2.7 & n.s. \\
\hline Width $\mathrm{x}$ est. treatment & 3.02 & & n.s. & 2.89 & $*$ & 6.09 & $* *$ \\
\hline Width $\mathrm{x}$ grazing & 0.00 & & n.s. & 1.64 & n.s. & 3.7 & * \\
\hline Width $\mathrm{x}$ grazing $\mathrm{x}$ est. treatment & 0.28 & & n.s. & 0.28 & n.s. & 0.82 & n.s. \\
\hline Year $\mathrm{x}$ est. treatment & 12.61 & & $* * *$ & 12.62 & $* * *$ & 4.49 & ** \\
\hline Year x grazing & 24.93 & & $* * *$ & 4.52 & $*$ & 1.15 & n.s. \\
\hline Year x Width & 0.89 & & n.s. & 0.71 & n.s. & 2.52 & * \\
\hline
\end{tabular}

* $P<0.05 .$, ** $P<0.01 .$, *** $P<0.001$.

Table 4. Effects of treatment, year, grazing and width and the interactions of these factors, on species turnover rates of the experimental plots over the establishment period (year 1- 2) and the experimental end point (year 5-

6) and long-term duration (year 2-6).

\begin{tabular}{llll}
\hline & \multicolumn{3}{c}{ Species turnover rate } \\
& $\boldsymbol{D F}$ & $\boldsymbol{F}$ & $\boldsymbol{P}$ \\
\hline Establishment treatment & $(2,36)$ & 6.92 & $* *$ \\
Grazing & $(1,36)$ & 9.58 & $* *$ \\
Grazing x est. treatment & $(2,36)$ & 1.52 & n.s. \\
Width & $(2,36)$ & 2.26 & n.s. \\
Width x est. treatment & $(4,36)$ & 1.42 & n.s. \\
Width x grazing & $(2,36)$ & 0.67 & n.s. \\
Width x grazing x est. treatment & $(4,36)$ & 0.54 & n.s. \\
Year x est. treatment & $(4,72)$ & 16.05 & $* * *$ \\
Year x grazing & $(2,72)$ & 4.69 & n.s. \\
Year x Width & $(4,72)$ & 0.85 & n.s. \\
Year x grazing x est. treatment & $(4,72)$ & 2.25 & n.s. \\
Year x width x est. treatment & $(8,72)$ & 0.97 & n.s. \\
Year x width x grazing x est. & $(12,72)$ & 0.80 & n.s. \\
treatment & & & \\
\hline$*<0.05 ., * * *<0.01 . . * * * P<0.001$. & & &
\end{tabular}


1 Table 5. F-values and significance of six separate Monte Carlo tests for the null hypothesis that species 2 composition (measured as percentage cover using the Braun-Blanquet scale) is the same in comparison to each 3 other in 2008 . $\mathrm{M}=$ Mown, $\mathrm{C}=$ grazed control, $\mathrm{R}+\mathrm{M}=$ rotavated $\&$ mown, $\mathrm{R}+\mathrm{G}=$ rotavated $\&$ grazed, $\mathrm{S}+\mathrm{M}=$ 4 seeded \& mown, $\mathrm{S}+\mathrm{G}=$ seeded \& grazed.

\begin{tabular}{lll}
\hline & $\boldsymbol{F}$ & $\boldsymbol{P}$ \\
\hline $\mathrm{M}$ vs $\mathrm{R}+\mathrm{M}$ & 1.728 & $\mathrm{~ns}$ \\
$\mathrm{M}$ vs $\mathrm{S}+\mathrm{M}$ & 10.616 & $* * *$ \\
$\mathrm{R}+\mathrm{M}$ vs $\mathrm{S}+\mathrm{M}$ & 5.718 & $* *$ \\
$\mathrm{C}$ vs $\mathrm{R}+\mathrm{G}$ & 3.134 & $* *$ \\
$\mathrm{C}$ vs $\mathrm{S}+\mathrm{G}$ & 5.827 & $* * *$ \\
$\mathrm{R}+\mathrm{G}$ vs $\mathrm{S}+\mathrm{G}$ & 5.827 & $* * *$ \\
\hline$* P<0.05 ., * * P<0.01 .$, & $* * * P<0.001$.
\end{tabular}

6

7 Table 6. F-values and significance of six separate Monte Carlo tests for the null hypothesis that species 8 composition is effected by specific treatments and their interactions in 2008.

\begin{tabular}{lll}
\hline & F & P \\
\hline Establishment treatment & 14.797 & $* * *$ \\
Grazing & 14.797 & $* * *$ \\
Width & 1.605 & ns \\
Grazing x est. treatment & 1.999 & $* *$ \\
Width x est. treatment & 0.790 & ns \\
Width x grazing x est. treatment & 0.94 & ns \\
\hline
\end{tabular}

$* P<0.05$., ** $P<0.01$., *** $P<0.001$. 
1

(a)

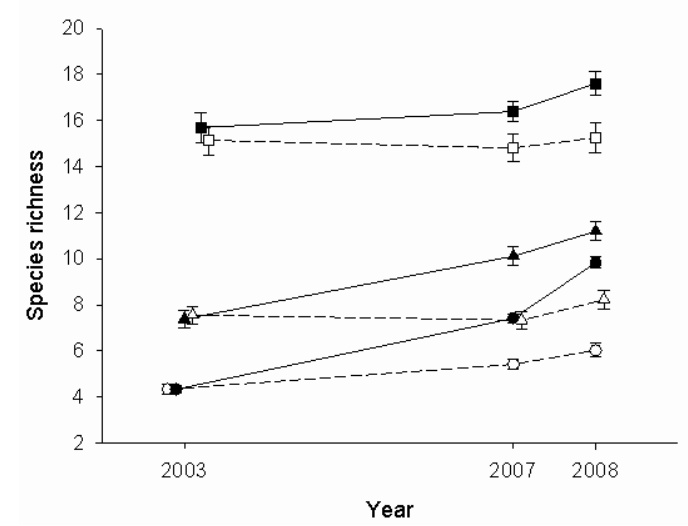

(c)

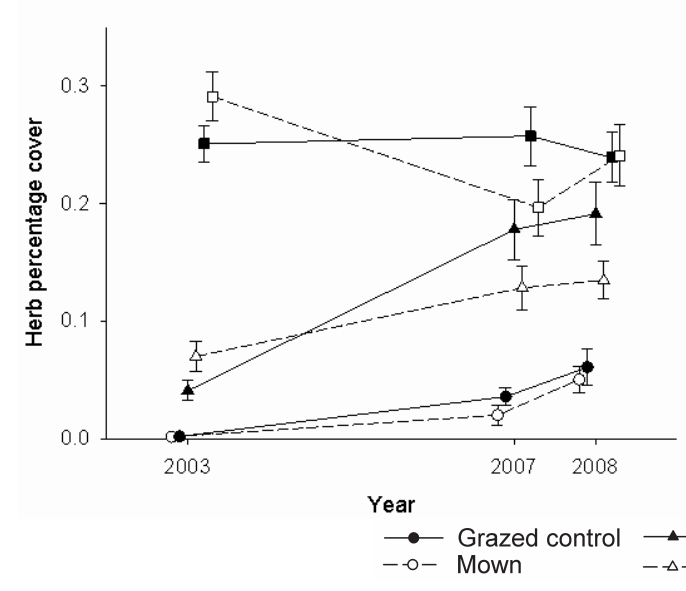

(b)

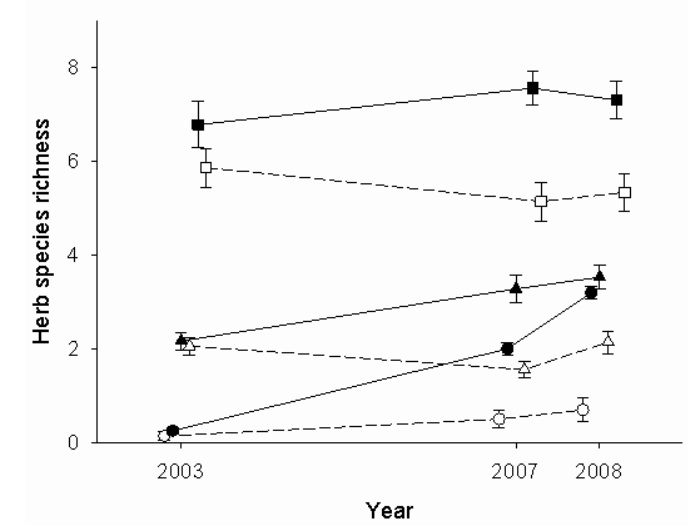

(d)

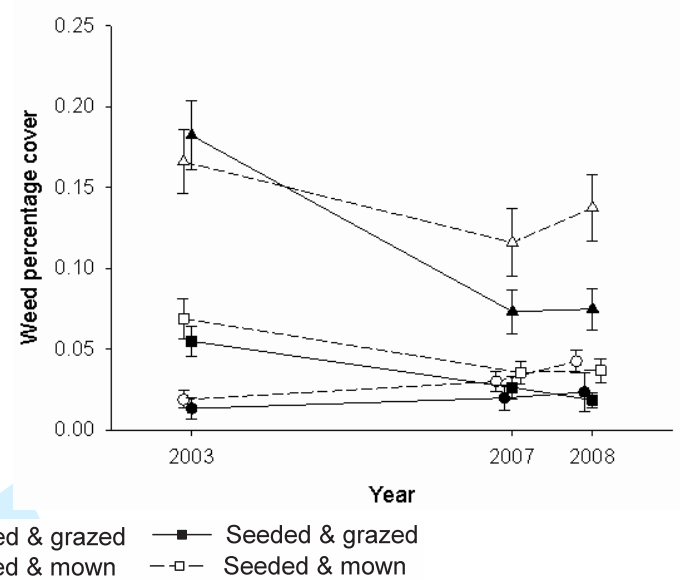

Fig.1. Year-to-year changes in mean (a) total species richness, (b) herb species richness, (c) herb cover, and (d) weed cover with error bars denoting SE $(n=36)$. 
(a)

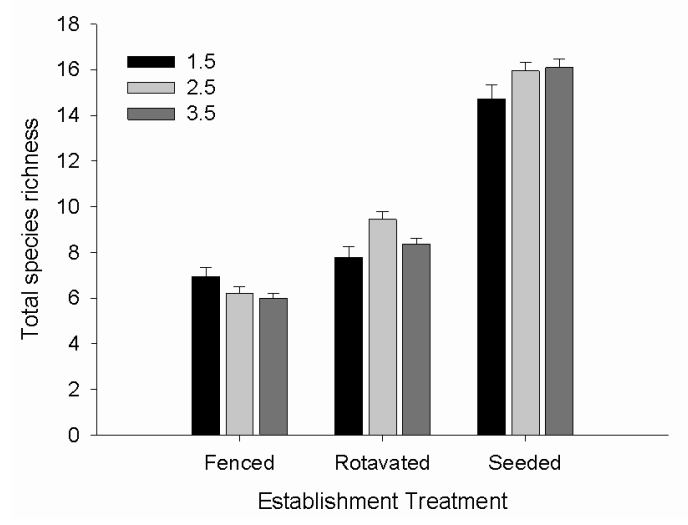

(b)

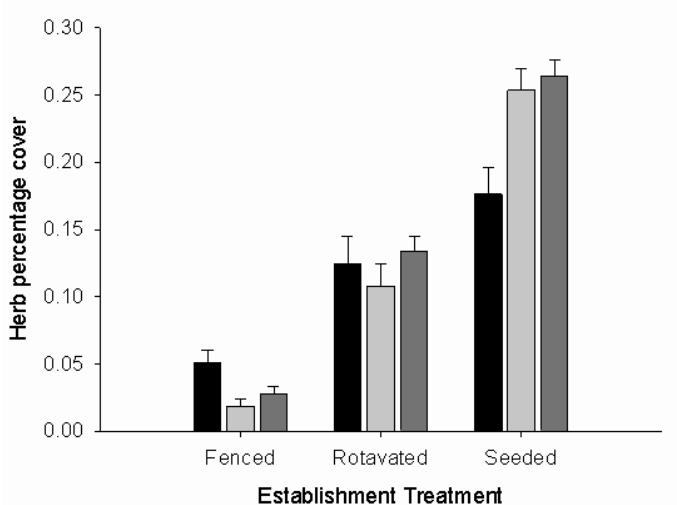

(c)

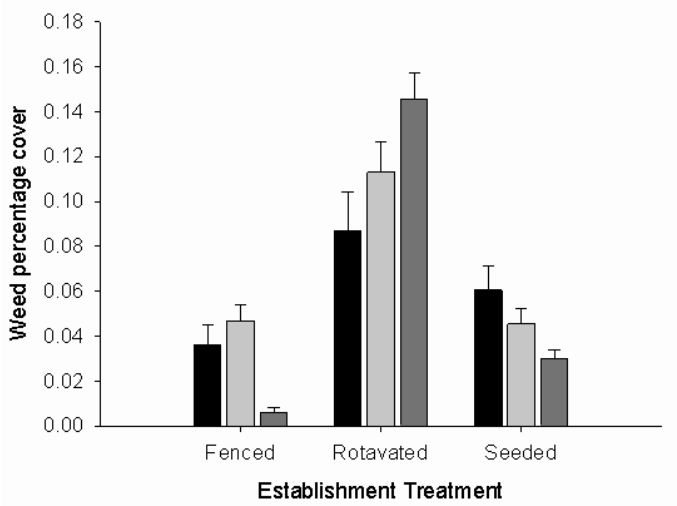

Fig. 2. Responses of (a) total species richness (mean species per quadrat $\pm \mathrm{SE}$ ), (b) herb percentage cover (mean cover per quadrat $\pm \mathrm{SE}$ ), and (c) weed percentage cover (mean cover per quadrat $\pm \mathrm{SE}$ ) to establishment treatment and margin widths: 1.5 (black) 2.5 (light grey) 3.5 (dark grey) $(\mathrm{n}=36,72,108$ for $1.5,2.5 \& 3.5 \mathrm{~m}$ widths respectively). 


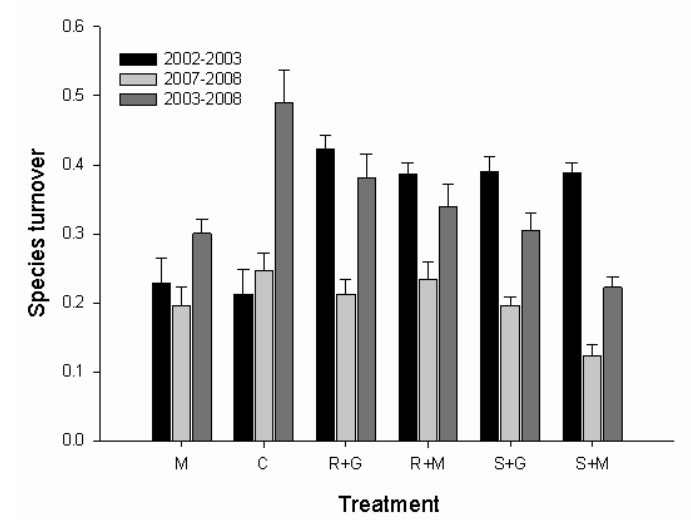

Fig. 3. Species turnover rates (mean turnover per quadrat \pm SE) within initial establishment period 2002-2003 (black), endpoint 2007-2008 (light-grey) and long-term turnover from 2003 to 2008 (dark-grey) of experiment within each establishment treatment $x$ grazing split-plot $(n=36)$. $M=$ Mown, $C=$ grazed control, $R+M=$ rotavated \& mown, $\mathrm{R}+\mathrm{G}=$ rotavated \& grazed, $\mathrm{S}+\mathrm{M}=$ seeded $\&$ mown, $\mathrm{S}+\mathrm{G}=$ seeded $\&$ grazed.

(a)

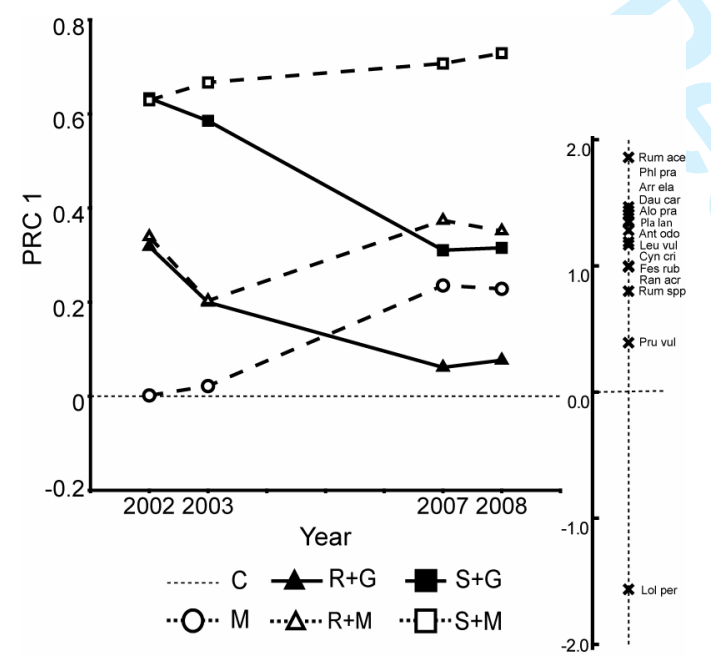

(b)

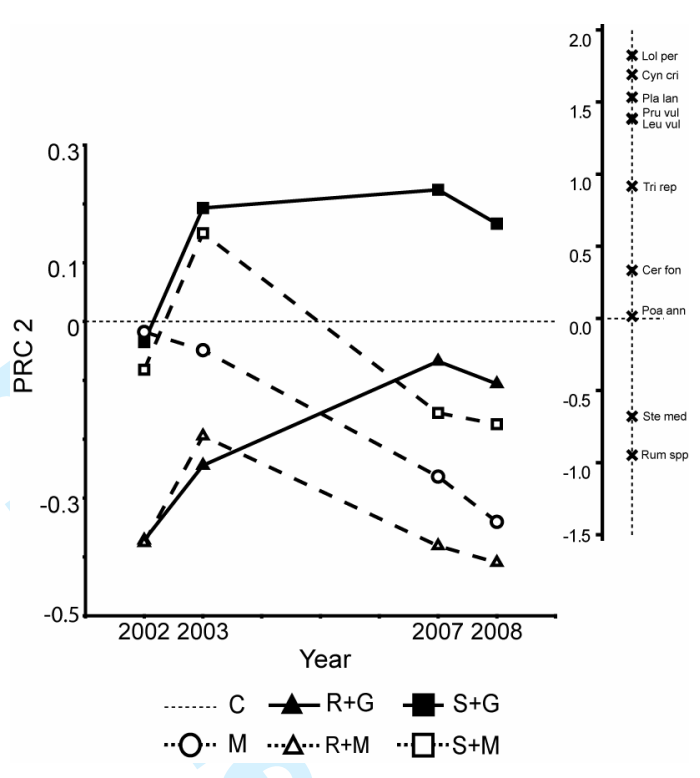

7

Fig. 4. Principal response curves (PRC) corresponding to the first (a) and second (b) partial RDA axis for plant community data (as percentage cover using the Braun Blanquet scale) change over time versus the grazed control, the zero line, with interactions between the treatments and time acting as environmental variables and sampling time indicators as co-variables. The one-dimensional diagram on the right shows the species scores on the RDA axis. Species which are highly associated with each axis are shown on the right of each panel. 
Fig. S1. Diagram of experimental design and plot locations (not to scale).

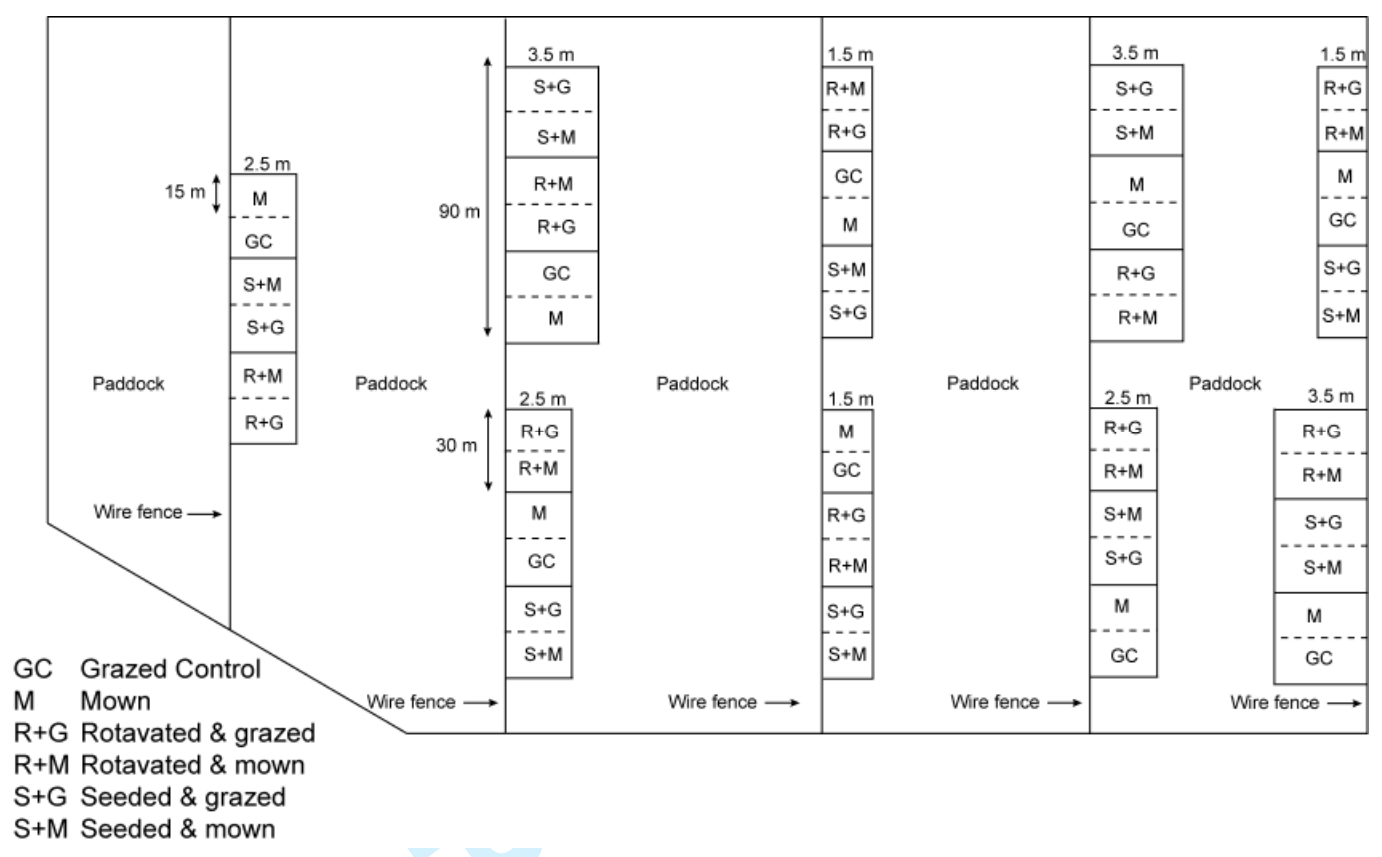


Fig. S2. Diagram of botanical sampling, quadrat sampling for $3.5 \mathrm{~m}$ margin width $a, b$, $\& c$ quadrats were sampled, at $2.5 \mathrm{~m}$ width $a \& b$ quadrats were sampled, in $1.5 \mathrm{~m}$ width $a$ quadrats were sampled (not to scale).

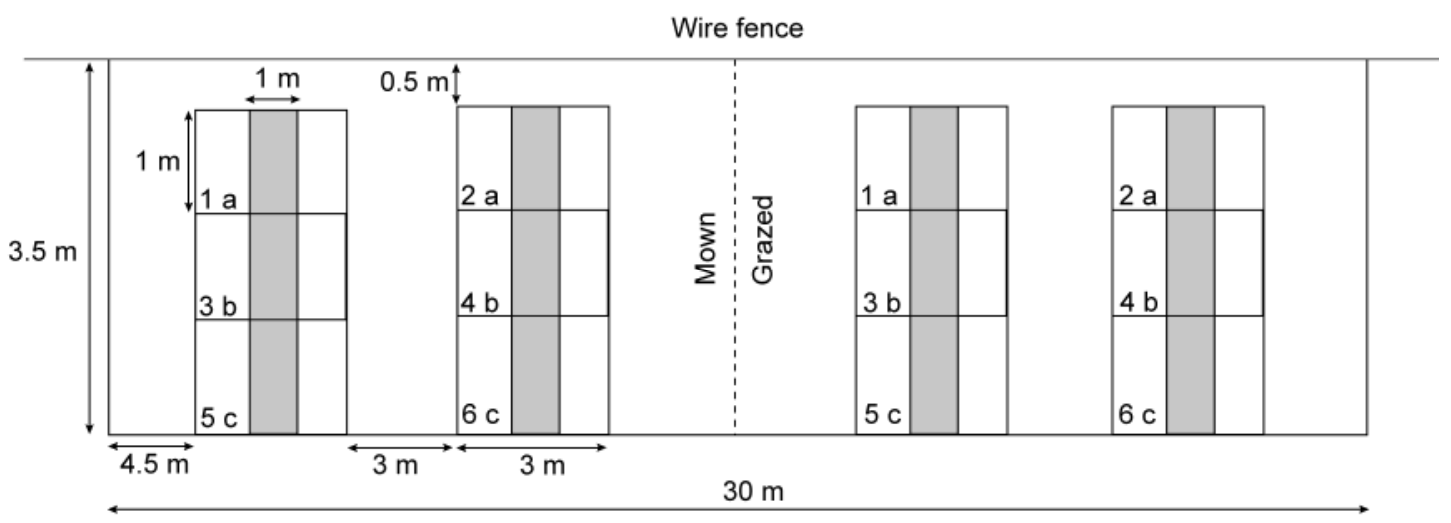


Table S1. List of presence/absence of all species recorded within experimental plots in 2002, 2003, 2007, and 2008.

\begin{tabular}{|c|c|c|c|c|c|c|c|c|c|c|c|c|c|c|c|c|c|c|c|c|c|c|c|c|}
\hline \multirow[b]{2}{*}{ Year } & \multirow[b]{2}{*}{02} & \multicolumn{3}{|c|}{ Mown } & \multicolumn{4}{|c|}{ Grazed Control } & \multicolumn{4}{|c|}{ Seeded \& Mown } & \multicolumn{4}{|c|}{$\begin{array}{c}\text { Seeded \& } \\
\text { Grazed }\end{array}$} & \multicolumn{4}{|c|}{$\begin{array}{c}\text { Rotavated \& } \\
\text { Mown }\end{array}$} & \multicolumn{4}{|c|}{$\begin{array}{c}\text { Rotavated \& } \\
\text { grazed }\end{array}$} \\
\hline & & 03 & 07 & 08 & 02 & 03 & 07 & 08 & 02 & 03 & 07 & 08 & 02 & 03 & 07 & 08 & 02 & 03 & 07 & 08 & 02 & 03 & 07 & 08 \\
\hline Acer spp & & & & & & & & & & & & $\mathrm{x}$ & & & & & & & & & & & & $\mathrm{x}$ \\
\hline Achillea millefolium & & & & & & & & & $\mathrm{x}$ & & & & $\mathrm{x}$ & $\mathrm{x}$ & $\mathrm{x}$ & $\mathrm{x}$ & & & & & & & & \\
\hline Agrostis gigantea & & & & & & & & & $\mathrm{x}$ & & & & & & & & & & & & & & & \\
\hline Agrostis spp & $\mathrm{x}$ & $\mathrm{x}$ & $\mathrm{x}$ & $\mathrm{x}$ & $\mathrm{x}$ & $\mathrm{x}$ & $\mathrm{x}$ & $\mathrm{x}$ & $\mathrm{x}$ & $\mathrm{x}$ & $\mathrm{x}$ & $\mathrm{x}$ & $\mathrm{x}$ & $\mathrm{x}$ & $\mathrm{x}$ & $\mathrm{x}$ & $\mathrm{x}$ & $\mathrm{x}$ & $\mathrm{x}$ & $\mathrm{x}$ & $\mathrm{x}$ & $\mathrm{x}$ & $\mathrm{x}$ & $\mathrm{x}$ \\
\hline Alopecurus geniculatus & & & & & & & & $\mathrm{x}$ & & & & $\mathrm{x}$ & & $\mathrm{x}$ & & $\mathrm{x}$ & & $\mathrm{x}$ & & & & $\mathrm{x}$ & & \\
\hline Alopecurus pratensis & & & & $\mathrm{x}$ & $\mathrm{x}$ & & $\mathrm{x}$ & $\mathrm{x}$ & $\mathrm{x}$ & $\mathrm{x}$ & $\mathrm{x}$ & $\mathrm{x}$ & $\mathrm{x}$ & $\mathrm{x}$ & $\mathrm{x}$ & $\mathrm{x}$ & $\mathrm{x}$ & & $\mathrm{x}$ & $\mathrm{x}$ & $\mathrm{x}$ & $\mathrm{x}$ & & $\mathrm{x}$ \\
\hline Anagallis arvensis & & & & & & & & & $\mathrm{x}$ & & & & $\mathrm{x}$ & $\mathrm{x}$ & & & $\mathrm{x}$ & & & & $\mathrm{x}$ & & & \\
\hline Angelica sylvestris & & & & & & & & & & $\mathrm{x}$ & & & & & & & & & & & & & & \\
\hline Anthoxanthum odoratum & & & & & $\mathrm{x}$ & & $\mathrm{x}$ & & $\mathrm{x}$ & $\mathrm{x}$ & $\mathrm{x}$ & $\mathrm{x}$ & $\mathrm{x}$ & $\mathrm{x}$ & $\mathrm{x}$ & $\mathrm{x}$ & & $\mathrm{x}$ & $\mathrm{x}$ & $\mathrm{x}$ & & $\mathrm{x}$ & $\mathrm{x}$ & $\mathrm{x}$ \\
\hline Arctium minus & & & & & & & & & $\mathrm{x}$ & $\mathrm{x}$ & & & $\mathrm{x}$ & $\mathrm{x}$ & & & & & & & & & & \\
\hline Arrhenatherum elatius & $\mathrm{x}$ & & $\mathrm{x}$ & $\mathrm{x}$ & & & & & $\mathrm{x}$ & $\mathrm{x}$ & $\mathrm{x}$ & $\mathrm{x}$ & $\mathrm{x}$ & $\mathrm{x}$ & $\mathrm{x}$ & & $\mathrm{x}$ & $\mathrm{x}$ & $\mathrm{x}$ & $\mathrm{x}$ & $\mathrm{x}$ & $\mathrm{x}$ & $\mathrm{x}$ & \\
\hline Bellis perennis & & & & & & & $\mathrm{x}$ & & & & & & & & & $\mathrm{x}$ & & & & & & & $\mathrm{x}$ & $\mathrm{x}$ \\
\hline Capsella bursa-pastoris & & & & & & & & & $\mathrm{x}$ & & & & $\mathrm{x}$ & & & & & & & & & & & \\
\hline Carex ovalis & & & & & & & & & & & & & & & & & & & & $\mathrm{x}$ & & & & $\mathrm{x}$ \\
\hline Centaurea nigra & & & & & & & & & & $\mathrm{x}$ & $\mathrm{x}$ & $\mathrm{x}$ & & $\mathrm{x}$ & $\mathrm{x}$ & $\mathrm{x}$ & & & & & & $\mathrm{x}$ & & \\
\hline Cerastium fontanum & & & $\mathrm{x}$ & $\mathrm{x}$ & $\mathrm{x}$ & $\mathrm{x}$ & $\mathrm{x}$ & $\mathrm{x}$ & $\mathrm{x}$ & $\mathrm{x}$ & $\mathrm{x}$ & $\mathrm{x}$ & $\mathrm{x}$ & $\mathrm{x}$ & $\mathrm{x}$ & $\mathrm{x}$ & $\mathrm{x}$ & $\mathrm{x}$ & $\mathrm{x}$ & $\mathrm{x}$ & $\mathrm{x}$ & $\mathrm{x}$ & $\mathrm{x}$ & $\mathrm{x}$ \\
\hline Chenopodium album & & & & & & & & & $\mathrm{x}$ & & & & $\mathrm{x}$ & & & & & & & & & & & \\
\hline Cirsium arvense & $\mathrm{x}$ & $\mathrm{x}$ & $\mathrm{x}$ & $\mathrm{x}$ & $\mathrm{x}$ & $\mathrm{x}$ & $\mathrm{x}$ & $\mathrm{x}$ & $\mathrm{x}$ & $\mathrm{x}$ & $\mathrm{x}$ & $\mathrm{x}$ & $\mathrm{x}$ & $\mathrm{x}$ & $\mathrm{x}$ & $\mathrm{x}$ & $\mathrm{x}$ & $\mathrm{x}$ & $\mathrm{x}$ & $\mathrm{x}$ & $\mathrm{x}$ & $\mathrm{x}$ & $\mathrm{x}$ & $\mathrm{x}$ \\
\hline Cirsium vulgare & $\mathrm{x}$ & & & & & & $\mathrm{x}$ & $\mathrm{x}$ & $\mathrm{x}$ & $\mathrm{x}$ & & & $\mathrm{x}$ & $\mathrm{x}$ & $\mathrm{x}$ & $\mathrm{x}$ & $\mathrm{x}$ & $\mathrm{x}$ & & $\mathrm{x}$ & $\mathrm{x}$ & $\mathrm{x}$ & $\mathrm{x}$ & $\mathrm{x}$ \\
\hline Cynosurus cristatus & & & $\mathrm{x}$ & $\mathrm{x}$ & & & $\mathrm{x}$ & $\mathrm{x}$ & $\mathrm{x}$ & $\mathrm{x}$ & $\mathrm{x}$ & $\mathrm{x}$ & $\mathrm{x}$ & $\mathrm{x}$ & $\mathrm{x}$ & $\mathrm{x}$ & & $\mathrm{x}$ & $\mathrm{x}$ & $\mathrm{x}$ & & & $\mathrm{x}$ & $\mathrm{x}$ \\
\hline Dactylis glomerata & $\mathrm{x}$ & $\mathrm{x}$ & $\mathrm{x}$ & $\mathrm{x}$ & $\mathrm{x}$ & $\mathrm{x}$ & $\mathrm{x}$ & $\mathrm{x}$ & $\mathrm{x}$ & $\mathrm{x}$ & $\mathrm{x}$ & $\mathrm{x}$ & $\mathrm{x}$ & $\mathrm{x}$ & $\mathrm{x}$ & $\mathrm{x}$ & $\mathrm{x}$ & $\mathrm{x}$ & $\mathrm{x}$ & $\mathrm{x}$ & & $\mathrm{x}$ & $\mathrm{x}$ & $\mathrm{x}$ \\
\hline Daucus carota & & & $\mathrm{x}$ & $\mathrm{x}$ & & & $\mathrm{x}$ & $x$ & $\mathrm{x}$ & $\mathrm{x}$ & $\mathrm{x}$ & $\mathrm{x}$ & $\mathrm{x}$ & $\mathrm{x}$ & $\mathrm{x}$ & $\mathrm{x}$ & $\mathrm{x}$ & $\mathrm{x}$ & $\mathrm{x}$ & $\mathrm{x}$ & & & $\mathrm{x}$ & $\mathrm{x}$ \\
\hline Digitalis purpurea & & & & & & & & & $\mathrm{x}$ & $\mathrm{x}$ & & & $\mathrm{x}$ & $\mathrm{x}$ & & & & & & & & & & \\
\hline Elytrigia repens & & & $\mathrm{x}$ & $\mathrm{x}$ & & & & & & & & $\mathrm{x}$ & & & & & & & $\mathrm{x}$ & $\mathrm{x}$ & & & & $\mathrm{x}$ \\
\hline Epilobium spp & $\mathrm{x}$ & $\mathrm{x}$ & $\mathrm{x}$ & $\mathrm{x}$ & $\mathrm{x}$ & & $\mathrm{x}$ & $\mathrm{x}$ & $\mathrm{x}$ & $\mathrm{x}$ & $\mathrm{x}$ & $\mathrm{x}$ & $\mathrm{x}$ & $\mathrm{x}$ & & $\mathrm{x}$ & $\mathrm{x}$ & $\mathrm{x}$ & $\mathrm{x}$ & $\mathrm{x}$ & $\mathrm{x}$ & $\mathrm{x}$ & $\mathrm{x}$ & $\mathrm{x}$ \\
\hline Festuca rubra & & & & & & & $\mathrm{x}$ & & & $\mathrm{x}$ & $\mathrm{x}$ & $\mathrm{x}$ & & $\mathrm{x}$ & $\mathrm{x}$ & $\mathrm{x}$ & & $\mathrm{x}$ & $\mathrm{x}$ & $\mathrm{x}$ & & $\mathrm{x}$ & $\mathrm{x}$ & $\mathrm{x}$ \\
\hline Filipendula ulmaria & & & & & & & & & & $\mathrm{x}$ & $\mathrm{x}$ & $\mathrm{x}$ & & $\mathrm{x}$ & $\mathrm{x}$ & $\mathrm{x}$ & & & $\mathrm{x}$ & $\mathrm{x}$ & & & & \\
\hline Gnaphalium uliginosum & & & & & & & & & $\mathrm{x}$ & & & & $\mathrm{x}$ & & & & $\mathrm{x}$ & & & & $\mathrm{x}$ & & & \\
\hline Hedera helix & & & & & & & & & & & & & & & & & & & & $\mathrm{x}$ & & & & \\
\hline Heracleum sphondylium & & & & & & & & & & & & & & $\mathrm{x}$ & & & & & & & & & & \\
\hline Holcus lanatus & $\mathrm{x}$ & $\mathrm{x}$ & $\mathrm{x}$ & $\mathrm{x}$ & $\mathrm{x}$ & $\mathrm{x}$ & $\mathrm{x}$ & $\mathrm{x}$ & $\mathrm{x}$ & $\mathrm{x}$ & $\mathrm{x}$ & $\mathrm{x}$ & $\mathrm{x}$ & $\mathrm{x}$ & $\mathrm{x}$ & $\mathrm{x}$ & $\mathrm{x}$ & $\mathrm{x}$ & $\mathrm{x}$ & $\mathrm{x}$ & $\mathrm{x}$ & $\mathrm{x}$ & $\mathrm{x}$ & $\mathrm{x}$ \\
\hline Holcus mollis & $\mathrm{x}$ & $\mathrm{x}$ & $\mathrm{x}$ & $\mathrm{x}$ & $\mathrm{x}$ & $\mathrm{x}$ & & $\mathrm{x}$ & $\mathrm{x}$ & $\mathrm{x}$ & $\mathrm{x}$ & $\mathrm{x}$ & $\mathrm{x}$ & $\mathrm{x}$ & & $\mathrm{x}$ & $\mathrm{x}$ & $\mathrm{x}$ & $\mathrm{x}$ & $\mathrm{x}$ & $\mathrm{x}$ & $\mathrm{x}$ & $\mathrm{x}$ & $\mathrm{x}$ \\
\hline Isolepis setacea & & & & & & & & & & & & & & & & $\mathrm{x}$ & 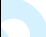 & & & & & & & $\mathrm{x}$ \\
\hline Juncus bufonius & $\mathrm{x}$ & & & & $\mathrm{x}$ & & & $\mathrm{x}$ & $\mathrm{x}$ & & & & $\mathrm{x}$ & & & $\mathrm{x}$ & $\mathrm{x}$ & & & & $\mathrm{x}$ & & & $\mathrm{x}$ \\
\hline Juncus spp & & & & & & & & $\mathrm{x}$ & & $\mathrm{x}$ & $\mathrm{x}$ & $\mathrm{x}$ & & & & $\mathrm{x}$ & & $\mathrm{x}$ & $\mathrm{x}$ & $\mathrm{x}$ & & $\mathrm{x}$ & $\mathrm{x}$ & $\mathrm{x}$ \\
\hline Leucanthemum vulgare & & & & & & & $\mathrm{x}$ & $\mathrm{x}$ & $\mathrm{x}$ & $\mathrm{x}$ & $\mathrm{x}$ & $\mathrm{x}$ & $\mathrm{x}$ & $\mathrm{x}$ & $\mathrm{x}$ & $\mathrm{x}$ & & $\mathrm{x}$ & & $\mathrm{x}$ & & $\mathrm{x}$ & & \\
\hline Lolium perenne & $\mathrm{x}$ & $\mathrm{x}$ & $\mathrm{x}$ & $\mathrm{x}$ & $\mathrm{x}$ & $\mathrm{x}$ & $\mathrm{x}$ & $\mathrm{x}$ & $\mathrm{x}$ & $\mathrm{x}$ & $\mathrm{x}$ & $\mathrm{x}$ & $\mathrm{x}$ & $\mathrm{x}$ & $\mathrm{x}$ & $\mathrm{x}$ & $\mathrm{x}$ & $x$ & $\mathrm{x}$ & $\mathrm{x}$ & $\mathrm{x}$ & $\mathrm{x}$ & $\mathrm{x}$ & $\mathrm{x}$ \\
\hline Lotus spp & & & & & & & & & $\mathrm{x}$ & $\mathrm{x}$ & & & $\mathrm{x}$ & $\mathrm{x}$ & & $\mathrm{x}$ & & & $\mathrm{x}$ & $\mathrm{x}$ & & & & \\
\hline Lychnis flos-cuculi & & & & & & & & & & $\mathrm{x}$ & $\mathrm{x}$ & $\mathrm{x}$ & & $\mathrm{x}$ & $\mathrm{x}$ & $\mathrm{x}$ & & & & & & & $\mathrm{x}$ & \\
\hline Matricaria discoidea & & & & & & & & & $\mathrm{x}$ & & & & $\mathrm{x}$ & & & & $\mathrm{x}$ & & & & $\mathrm{x}$ & & & \\
\hline Matricaria recutita & & & & & & & & & $\mathrm{x}$ & & & & $\mathrm{x}$ & & & & & & & & $\mathrm{x}$ & & & \\
\hline Medicago lupulina & & & & & & & & & $\mathrm{x}$ & & & & $\mathrm{x}$ & $\mathrm{x}$ & & & & & & & & & & \\
\hline Papaver rhoeas & & & & & & & & & $\mathrm{x}$ & & & & $\mathrm{x}$ & & & & & & & & & & & \\
\hline Persicaria maculata & & & & & & & & & $\mathrm{x}$ & & & & $\mathrm{x}$ & & & & $\mathrm{x}$ & & & & $\mathrm{x}$ & & & \\
\hline Phleum pratense & & & & & $\mathrm{x}$ & & & & $\mathrm{x}$ & $\mathrm{x}$ & $\mathrm{x}$ & $\mathrm{x}$ & $\mathrm{x}$ & $\mathrm{x}$ & $\mathrm{x}$ & $\mathrm{x}$ & $\mathrm{x}$ & $\mathrm{x}$ & $\mathrm{x}$ & $\mathrm{x}$ & $\mathrm{x}$ & & $\mathrm{x}$ & \\
\hline Plantago lanceolata & & & & & & & $\mathrm{x}$ & $\mathrm{x}$ & $\mathrm{x}$ & $\mathrm{x}$ & $\mathrm{x}$ & $\mathrm{x}$ & $\mathrm{x}$ & $\mathrm{x}$ & $\mathrm{x}$ & $\mathrm{x}$ & & $\mathrm{x}$ & & & & $\mathrm{x}$ & $\mathrm{x}$ & $\mathrm{x}$ \\
\hline Plantago major & & & & & & & & & & & & & $\mathrm{x}$ & & & $\mathrm{x}$ & & & & & $\mathrm{x}$ & & & \\
\hline Pоа аппиа & & & & $\mathrm{x}$ & & & $\mathrm{x}$ & $\mathrm{x}$ & $\mathrm{x}$ & & $\mathrm{x}$ & & $\mathrm{x}$ & & $\mathrm{x}$ & $\mathrm{x}$ & $\mathrm{x}$ & & $\mathrm{x}$ & & $\mathrm{x}$ & & $\mathrm{x}$ & $\mathrm{x}$ \\
\hline Poa pratensis & $\mathrm{x}$ & & & & & & & & & & & & $\mathrm{x}$ & & & & $\mathrm{x}$ & & & & $\mathrm{x}$ & & & \\
\hline Poa trivialis & $\mathrm{x}$ & $\mathrm{x}$ & $\mathrm{x}$ & $\mathrm{x}$ & $\mathrm{x}$ & $\mathrm{x}$ & $\mathrm{x}$ & $\mathrm{x}$ & $\mathrm{x}$ & $\mathrm{x}$ & $\mathrm{x}$ & $\mathrm{x}$ & $\mathrm{x}$ & $\mathrm{x}$ & $\mathrm{x}$ & $\mathrm{x}$ & $\mathrm{x}$ & $\mathrm{x}$ & $\mathrm{x}$ & $\mathrm{x}$ & $\mathrm{x}$ & $\mathrm{x}$ & $\mathrm{x}$ & $\mathrm{x}$ \\
\hline Polygonum aviculare & & & & & & & & & & & & & & & & & $\mathrm{x}$ & & & & & & & \\
\hline
\end{tabular}




\begin{tabular}{|c|c|c|c|c|c|c|c|c|c|c|c|c|c|c|c|c|c|c|c|c|c|c|c|c|}
\hline Potentilla anglica & & & & & & & & & & & & & & & & & & & & $\mathrm{x}$ & & & & \\
\hline Prunella vulgaris & & & & & & & $\mathrm{x}$ & $\mathrm{x}$ & & $\mathrm{x}$ & $\mathrm{x}$ & $\mathrm{x}$ & & $\mathrm{x}$ & $\mathrm{x}$ & $\mathrm{x}$ & $\mathrm{x}$ & $\mathrm{x}$ & & & & & $\mathrm{x}$ & $\mathrm{x}$ \\
\hline Quercus spp & $\mathrm{x}$ & & $\mathrm{x}$ & $\mathrm{x}$ & & & & $\mathrm{x}$ & & & $\mathrm{x}$ & $\mathrm{x}$ & & & & & & & $\mathrm{x}$ & $\mathrm{x}$ & & & & \\
\hline Ranunculus acris & & & & & & & $\mathrm{x}$ & & & $\mathrm{x}$ & $\mathrm{x}$ & $\mathrm{x}$ & & $\mathrm{x}$ & $\mathrm{x}$ & $\mathrm{x}$ & & & & & & & & \\
\hline Ranunculus repens & $\mathrm{x}$ & $\mathrm{x}$ & $\mathrm{x}$ & $\mathrm{x}$ & $\mathrm{x}$ & $\mathrm{x}$ & $\mathrm{x}$ & $\mathrm{x}$ & $\mathrm{x}$ & $\mathrm{x}$ & $\mathrm{x}$ & $\mathrm{x}$ & $\mathrm{x}$ & $\mathrm{x}$ & $\mathrm{x}$ & $\mathrm{x}$ & $\mathrm{x}$ & $\mathrm{x}$ & $\mathrm{x}$ & $\mathrm{x}$ & $\mathrm{x}$ & $\mathrm{x}$ & $\mathrm{x}$ & $\mathrm{x}$ \\
\hline Rubus fruticosus & & & & & & & & & & & & & & & & & $\mathrm{x}$ & $\mathrm{x}$ & & & & $\mathrm{x}$ & & \\
\hline Rumex acetosa & & & $\mathrm{x}$ & $\mathrm{x}$ & & & $\mathrm{x}$ & $\mathrm{x}$ & $\mathrm{x}$ & $\mathrm{x}$ & $\mathrm{x}$ & $\mathrm{x}$ & $\mathrm{x}$ & $\mathrm{x}$ & $\mathrm{x}$ & $\mathrm{x}$ & & $\mathrm{x}$ & $\mathrm{x}$ & $\mathrm{x}$ & & $\mathrm{x}$ & $\mathrm{x}$ & $\mathrm{x}$ \\
\hline Rumex acetosella & & & & & & & & & & & & $\mathrm{x}$ & & $\mathrm{x}$ & & $\mathrm{x}$ & $\mathrm{x}$ & $\mathrm{x}$ & & & & & & \\
\hline Rumex spp & $\mathrm{x}$ & $\mathrm{x}$ & $\mathrm{x}$ & $\mathrm{x}$ & $\mathrm{x}$ & $\mathrm{x}$ & $\mathrm{x}$ & $\mathrm{x}$ & $\mathrm{x}$ & $\mathrm{x}$ & $\mathrm{x}$ & $\mathrm{x}$ & $\mathrm{x}$ & $\mathrm{x}$ & $\mathrm{x}$ & $\mathrm{x}$ & $\mathrm{x}$ & $\mathrm{x}$ & $\mathrm{x}$ & $\mathrm{x}$ & $\mathrm{x}$ & $\mathrm{x}$ & $\mathrm{x}$ & $\mathrm{x}$ \\
\hline Sagina procumbens & & & & & & & & $\mathrm{x}$ & & & & & & & & $\mathrm{x}$ & & & & & & & & \\
\hline Salix spp & & & & & & & & & & & & & & & & & & $\mathrm{x}$ & & & & $\mathrm{x}$ & & \\
\hline Senecio jacobaea & & $\mathrm{x}$ & & $\mathrm{x}$ & & $\mathrm{x}$ & $\mathrm{x}$ & $\mathrm{x}$ & $\mathrm{x}$ & $\mathrm{x}$ & $\mathrm{x}$ & $\mathrm{x}$ & $\mathrm{x}$ & $\mathrm{x}$ & $\mathrm{x}$ & $\mathrm{x}$ & $\mathrm{x}$ & $\mathrm{x}$ & $\mathrm{x}$ & $\mathrm{x}$ & $\mathrm{x}$ & $\mathrm{x}$ & $\mathrm{x}$ & $\mathrm{x}$ \\
\hline Senecio vulgaris & & & & & & & & & & & & & $\mathrm{x}$ & & & & $\mathrm{x}$ & & & & $\mathrm{x}$ & & & \\
\hline Silene vulgaris & & & & & & & & & $\mathrm{x}$ & & & & $\mathrm{x}$ & & & & & & & & & & & \\
\hline Sonchus asper & & & & & & & & & $\mathrm{x}$ & & & & $\mathrm{x}$ & & & & $\mathrm{x}$ & & & & $\mathrm{x}$ & & & \\
\hline Sonchus oleraceus & & & & & & & & & $\mathrm{x}$ & & & & $\mathrm{x}$ & & & & $\mathrm{x}$ & & $\mathrm{x}$ & & $\mathrm{x}$ & $\mathrm{x}$ & $\mathrm{x}$ & \\
\hline Spergula arvensis & & & & & & & & & $\mathrm{x}$ & & & & $\mathrm{x}$ & & & & $\mathrm{x}$ & & & & $\mathrm{x}$ & & & \\
\hline Stellaria graminea & & & & & & & & & & & $\mathrm{x}$ & $\mathrm{x}$ & & & & & & & & & & & & \\
\hline Stellaria media & & & & & & $\mathrm{x}$ & $\mathrm{x}$ & $\mathrm{x}$ & $\mathrm{x}$ & & $\mathrm{x}$ & $\mathrm{x}$ & $\mathrm{x}$ & & $\mathrm{x}$ & & $\mathrm{x}$ & & $\mathrm{x}$ & $\mathrm{x}$ & $\mathrm{x}$ & & $\mathrm{x}$ & $\mathrm{x}$ \\
\hline Succisa pratensis & & & & & & & & & & & & & & $\mathrm{x}$ & & & & & & & & & & \\
\hline Taraxacum spp & & $\mathrm{x}$ & & & $\mathrm{x}$ & & $\mathrm{x}$ & $\mathrm{x}$ & $\mathrm{x}$ & $\mathrm{x}$ & $\mathrm{x}$ & $\mathrm{x}$ & $\mathrm{x}$ & $\mathrm{x}$ & $\mathrm{x}$ & $\mathrm{x}$ & $\mathrm{x}$ & & & $\mathrm{x}$ & $\mathrm{x}$ & $\mathrm{x}$ & $\mathrm{x}$ & $\mathrm{x}$ \\
\hline Trifolium pratense & & & & & & & & & $\mathrm{x}$ & $\mathrm{x}$ & & & $\mathrm{x}$ & $\mathrm{x}$ & & & & & & & & & & \\
\hline Trifolium repens & $\mathrm{x}$ & & $\mathrm{x}$ & $\mathrm{x}$ & $\mathrm{x}$ & & $\mathrm{x}$ & $\mathrm{x}$ & $\mathrm{x}$ & $\mathrm{x}$ & $\mathrm{x}$ & $\mathrm{x}$ & $\mathrm{x}$ & $\mathrm{x}$ & $\mathrm{x}$ & $\mathrm{x}$ & $\mathrm{x}$ & $\mathrm{x}$ & $\mathrm{x}$ & $\mathrm{x}$ & $\mathrm{x}$ & $\mathrm{x}$ & $\mathrm{x}$ & $\mathrm{x}$ \\
\hline Urtica dioica & & & & & $\mathrm{x}$ & $\mathrm{x}$ & & & $\mathrm{x}$ & $\mathrm{x}$ & $\mathrm{x}$ & $\mathrm{x}$ & $\mathrm{x}$ & $\mathrm{x}$ & & & $\mathrm{x}$ & $\mathrm{x}$ & $\mathrm{x}$ & $\mathrm{x}$ & $\mathrm{x}$ & $\mathrm{x}$ & $\mathrm{x}$ & $\mathrm{x}$ \\
\hline Veronica serpyllifolia & & & & & $\mathrm{x}$ & & & $\mathrm{x}$ & & & & $\mathrm{x}$ & $\mathrm{x}$ & $\mathrm{x}$ & $\mathrm{x}$ & $\mathrm{x}$ & $\mathrm{x}$ & & & & $\mathrm{x}$ & $\mathrm{x}$ & $\mathrm{x}$ & $\mathrm{x}$ \\
\hline
\end{tabular}


Table S2. Mean soil nutrient levels for phosphate $(\mathrm{P})$, potassium $(\mathrm{K})$, and magnesium $(\mathrm{Mg})$ and standard error for establishment year (2002) before grazing commenced and final year (2008). Treatments are within main sward (F), mown $(\mathrm{M})$, grazed control $(\mathrm{C})$, rotavated and mown $(\mathrm{S}+\mathrm{M})$, rotavated and grazed $(\mathrm{R}+\mathrm{G})$, seeded and mown $(\mathrm{S}+\mathrm{M})$, seeded and grazed $(\mathrm{S}+\mathrm{G})$.

\begin{tabular}{|c|c|c|c|c|c|c|c|c|c|}
\hline \multirow{2}{*}{$\begin{array}{c}\text { Year } \\
\text { Treatment }\end{array}$} & \multicolumn{3}{|c|}{2002} & \multicolumn{6}{|c|}{2008} \\
\hline & Fenced & Seeded & Rotavated & M & $\mathrm{C}$ & $\mathrm{S}+\mathrm{M}$ & $\mathrm{S}+\mathrm{G}$ & $\mathrm{R}+\mathrm{M}$ & $\mathrm{R}+\mathrm{G}$ \\
\hline $\mathrm{P}$ & 4.12 & 3.66 & 3.76 & 3.54 & 4.84 & 4.28 & 4.9 & 3.88 & 4.43 \\
\hline SE P & 0.27 & 0.25 & 0.37 & 0.23 & 0.35 & 0.42 & 0.28 & 0.3 & 0.3 \\
\hline $\mathrm{K}$ & 64.23 & 94.22 & 69.67 & 58.56 & 145.56 & 67.73 & 131.88 & 63.62 & 127.4 \\
\hline SE K & 4.77 & 13.31 & 5.99 & 7.19 & 13.61 & 4.98 & 19.46 & 10.34 & 16.25 \\
\hline $\mathrm{Mg}$ & 202.88 & 193.89 & 178.33 & 162.56 & 188.53 & 165.39 & 178.4 & 171.27 & 178.7 \\
\hline SE Mg & 11.93 & 13.42 & 7.4 & 4.99 & 9.13 & 11.13 & 9.03 & 8.33 & 4.87 \\
\hline
\end{tabular}


Table S3. Effects of establishment treatment, grazing and width on Morgan's soil phosphate (P), potassium (K), and magnesium $(\mathrm{Mg})$ of the experimental plots in 2008 .

\begin{tabular}{|c|c|c|c|c|c|c|c|}
\hline & & \multicolumn{2}{|c|}{$\mathbf{P}$} & \multicolumn{2}{|c|}{$\mathbf{K}$} & \multicolumn{2}{|c|}{ Mg } \\
\hline & & $F$ & $P$ & $F$ & $P$ & $F$ & $P$ \\
\hline Establishment treatment & $(2,40)$ & 0.24 & n.s.. & 1.26 & n.s. & 0.4 & n.s. \\
\hline Width & $(2,40)$ & 0.45 & n.s. & 22.82 & $* * *$ & 5.61 & $* *$ \\
\hline Grazing & $(1,40)$ & 2.11 & n.s. & 665.45 & $* * *$ & 18.55 & $* * *$ \\
\hline Est. treat $\mathrm{x}$ width & $(4,40)$ & 0.15 & n.s. & 16.73 & $* * *$ & 1.33 & n.s. \\
\hline Est. treat $\mathrm{x}$ grazing & $(2,40)$ & 0.19 & n.s. & 7.61 & $* *$ & 2.28 & n.s. \\
\hline Grazing x width & $(2,40)$ & 0.21 & n.s. & 5.1 & $*$ & 0.38 & n.s. \\
\hline
\end{tabular}

$* P<0.05 ., * * P<0.01 ., * * * P<0.001$. 